\title{
EFFECT OF DIFFERENT PARAMETERS AND STORAGE CONDITIONS ON LIQUID JAGGERY WITHOUT ADDING PRESERVATIVES
}

\author{
Supriya.D.Patil ${ }^{1}$, S.V.Anekar ${ }^{2}$ \\ ${ }^{I}$ M.E student, Chemical Department, TKIET Warnanagar, Maharashtra, India \\ ${ }^{2}$ Professor, Chemical Department, TKIET Warnanagar, Maharashtra, India
}

\begin{abstract}
Jaggery industry is a cottage industry in India. In today's world liquid jaggery has been gaining a much importance due to its nutritional value. Studies were conducted to investigate the parameters affecting shelf life such $\mathrm{pH}$, colour, brix, moisture content and range of temperatures on the concentration of reducing sugars. The variety Co86032 was selected to observe the effect of storage period on quality characteristics of liquid jaggery. Samples were stored at three different conditions i.e. room temperature $\left(27^{\circ} \mathrm{C}\right)$, refrigeration $\left(7^{\circ} \mathrm{C}\right)$ and high temperature $\left(37^{\circ} \mathrm{C}\right)$ in pre-sterilized PET bottles for 90 days .In order to optimize the changes in properties physico-chemical tests were evaluated during storage. The $p H$ decreased significantly, whereas, moisture content and reducing sugar increased significantly during storage. The changes in different attributes were significantly higher at $37^{\circ} \mathrm{C}$ temperature as compared to room temperature and refrigeration temperature. The results revealed that change in chemical composition was lower in case of refrigerated sample. Refrigerated sample was found more acceptable among other two samples after storage period of three months in terms of its chemical properties.
\end{abstract}

Keywords: Liquid jaggery, without preservatives, Shelf life, Storage.

\section{INTRODUCTION}

Sugarcane belongs to the genus saccharum of the grass family which is used as a raw material for manufacturing of jaggery [1]. There are three types of jaggery namely solid jaggery, liquid jaggery and granular jaggery. Out of the total production of jaggery in India $20 \%$ jaggery is produced in liquid and granular form and $80 \%$ is produced in solid form[2]. Liquid jaggery is alternative source to honey. Sugarcane crushing is the first step in liquid jaggery manufacturing process .It is an intermediate product collected during jaggery manufacturing and striking temperature of it ranges from $105^{\circ} \mathrm{C}$ to $108^{\circ} \mathrm{C}$ or generally it depends upon the varieties of sugarcane used. The composition of liquid jaggery per $100 \mathrm{gm}$ is: water 30 $35 \mathrm{gm}$,invert sugar $15-25 \mathrm{gm}$, sucrose $40-60 \mathrm{gm}$, fat $0.1 \mathrm{gm}$, protein $0.5 \mathrm{gm}$ and total minerals $0.75 \mathrm{gm}$. Calorific value of liquid jaggery is $300 \mathrm{Kcal} / 100 \mathrm{gm}$.[3]To increase the shelf life of liquid jaggery preservatives like $0.1 \%$ of potassium met bisulphate or $0.5 \%$ of benzoic acid is added. Liquid jaggery is used as sweetening agent in daily diet in Maharashtra, Tamilnadu, Gujrat, Andhrapradesh, Kerala.[4]

\section{MATERIALS AND METHODS}

The variety Co86032 was selected from promising varieties of sugarcane to study shelf life of liquid jaggery. Samples of liquid jaggery were stored at room temperature $\left(27^{\circ} \mathrm{C}\right)$ refrigeration $\left(7^{\circ} \mathrm{C}\right)$ and $37^{\circ} \mathrm{C}$ temperature in pre-sterilized PET bottles and analysed for physico-chemical properties at every 15 days of interval for 90 days.

\subsection{Methods of Analysis of Quality Parameters}

\section{Moisture Content}

The moisture content of the sample was determined using vacuum oven method. $10 \mathrm{~g}$ of the sample was weighed and placed into a pre-weighed crucible and then dried at $105^{\circ} \mathrm{C}$ till the dryness occurs.

\section{Brix}

A hand held refractometer with 0 to 90 brix scale was used for brix measurement. 1-2 drops of liquid jaggery was placed onto a prism and value of brix was recorded.

\section{pH}

$\mathrm{pH}$ meter was used for $\mathrm{pH}$ measurements. The $\mathrm{pH}$ meter was calibrated using $\mathrm{pH} 7$ and $\mathrm{pH} 4$ standard solutions.

\section{Reducing Sugar}

The reducing sugar was determined by DNSA method, using DNS reagent $(1 \mathrm{~g}$ of dinitrosalycilic acid; $70 \mathrm{ml}$ of $\mathrm{NaOH}$ at $0.5 \mathrm{~N} ; 30 \mathrm{~g}$ of Potassium Sodium tartarate tetra hydrate)With working standard $1 \mathrm{mg} / \mathrm{ml}$ (50mgdextrose $/ 50 \mathrm{ml}$ distilled water) and measured the absorbance at $540 \mathrm{~nm}$.Standard graph was plotted as shown in chart1. 


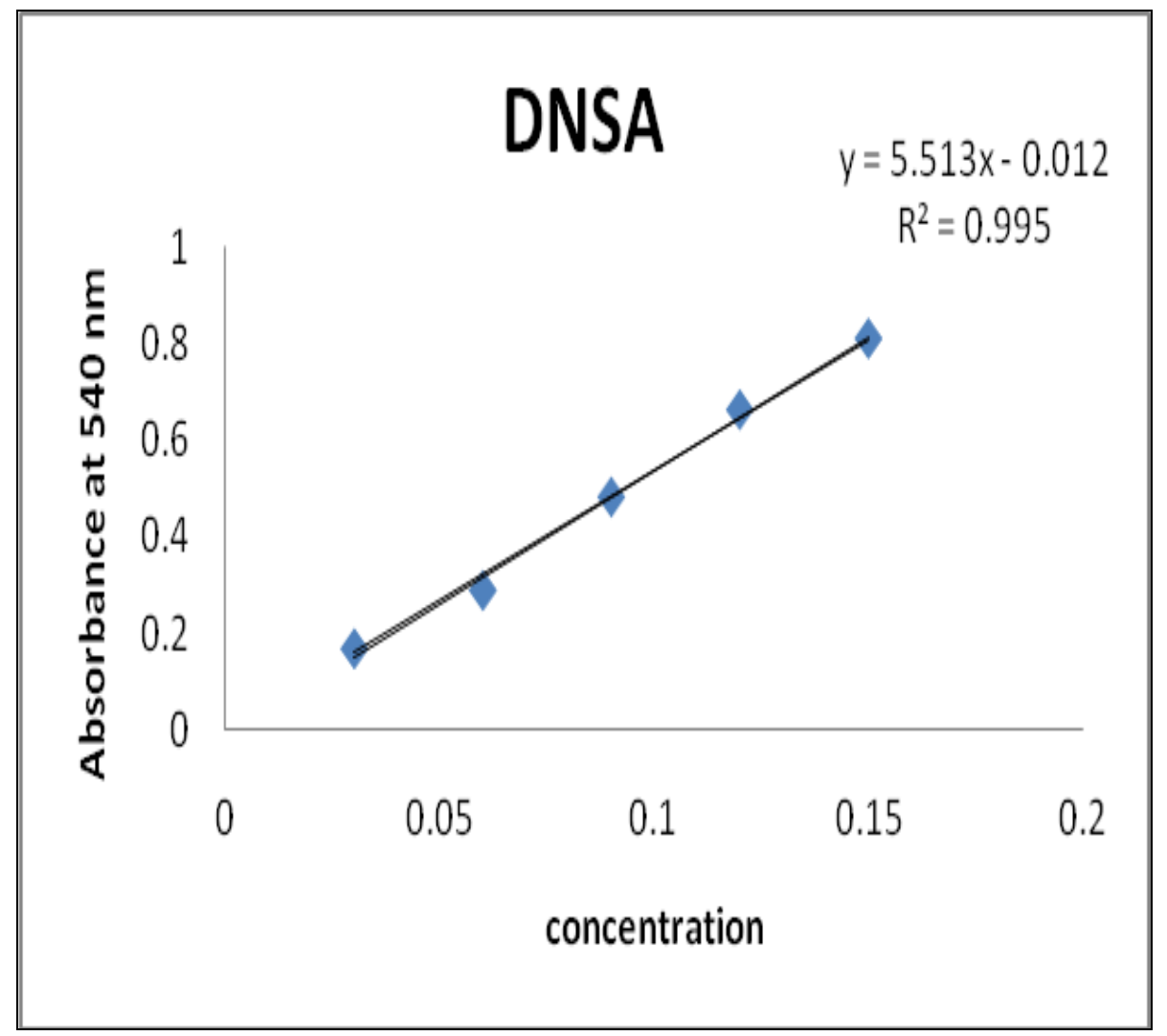

Chart-1: Standard graph for DNSA method

\section{Colour}

Hunter L, a, and b colour scale was selected for all measurements. Samples were kept on the specimen port (95mm diameter) to cover the full exposed area of the port to the light. All measurements were replicated thrice and the mean readings were taken. The $L, a$ and $b$ values are three dimensions of a measured colour which gives specific colour value of the material. Colour difference $(\Delta \mathrm{E})$ indicates the degree of overall colour change of a sample in comparison to colour values of an standard sample having colour values of $\mathrm{L}^{*}, \mathrm{a}^{*}$, and $\mathrm{b}^{*}$.The colours of the samples represents in terms of $\mathrm{L}$ (whiteness/darkness), a (redness/greenness), b (yellowness/blueness). Colour difference was calculated using equation 1 ,

$$
\Delta E=\sqrt{\left(L-L^{*}\right)^{2}+\left(a-a^{*}\right)^{2}+\left(b-b^{*}\right)^{2}}
$$

\section{RESULTS AND DISCUSSION}

\subsection{Chemical Composition of Liquid Jaggery}

The chemical composition of liquid jaggery (var.Co 86032) was determined in Table 1. Fresh liquid jaggery was analyzed for physic-chemical evaluation before storage. On estimation, liquid jaggery was found to contain $19 \%$ moisture content, $4.91 \mathrm{pH}, 71$ brix and $13 \%$ reducing sugar. Maximum colour difference was observed in sample at $37^{\circ} \mathrm{C}$ temperature.
Table -1: Chemical composition of liquid jaggery

\begin{tabular}{|l|l|}
\hline Properties & Value \\
\hline Moisture content\% & 19 \\
\hline $\mathrm{pH}$ & 4.91 \\
\hline Brix & 71 \\
\hline reducing sugar \% & 13 \\
\hline Density $\left(\mathrm{g} / \mathrm{cm}^{3}\right)$ & 1.34 \\
\hline
\end{tabular}

\subsection{Effect of Parameters on Chemical Properties of}

\section{Liquid Jaggery on Storage}

The data of effect of parameters on liquid jaggry during storage on moisture content, $\mathrm{pH}$, brix, reducing sugar and colour of liquid jaggery is depicted in Table 2. The results revealed that moisture content of liquid jaggery significantly increased during storage period .This may be due to the high water vapour transmission rate of PET bottles due to which there was increase in moisture content of liquid jaggery.The moisture content of liquid jaggery ranged from 19 to 20.9 per cent. Maximum moisture was observed at $37^{\circ} \mathrm{C}$ temperature stored for 90 days while minimum water absorption after 90 days of storage was observed at refrigeration temperature. There was no significant change observed in brix. The content of reducing sugar increased significantly during storage in liquid jaggery at room, refrigeration, $37^{\circ} \mathrm{C}$ temperature may be due to the hydrolysis of sugars, however, the decrease was lesser at refrigeration temperature. The $\mathrm{pH}$ of liquid jaggery samples decreased significantly and it found to be reversibly related to storage period. This decrease in $\mathrm{pH}$ may be due to change in chemical properties which are affected by storage condition. 
Table - 2: Effect of different parameters and storage on physic-chemical properties of liquid jaggey

\begin{tabular}{|c|c|c|c|c|c|c|c|c|c|}
\hline & & & Days & & & & & & \\
\hline Sr No & Parameter & Temperature & 0 & 15 & 30 & 45 & 60 & 75 & 90 \\
\hline \multirow{3}{*}{1} & \multirow{3}{*}{ Moisture } & $\operatorname{Room}\left(27^{\circ} \mathrm{C}\right)$ & 19 & 19.2 & 19.6 & 19.7 & 19.9 & 20.2 & 20.5 \\
\hline & & Refrigeration $\left(7^{\circ} \mathrm{C}\right)$ & 19 & 19.1 & 19.3 & 19.4 & 19.7 & 19.9 & 20.1 \\
\hline & & $\left(37^{\circ} \mathrm{C}\right)$ & 19 & 19.5 & 19.8 & 19.9 & 20.3 & 20.7 & 20.9 \\
\hline \multirow{3}{*}{2} & \multirow{3}{*}{$\mathrm{pH}$} & $\operatorname{Room}\left(27^{\circ} \mathrm{C}\right)$ & 5.28 & 5.27 & 5.26 & 5.15 & 5.02 & 4.91 & 4.8 \\
\hline & & Refrigeration $\left(7^{\circ} \mathrm{C}\right)$ & 5.28 & 5.23 & 5.20 & 5.13 & 5.07 & 5.04 & 5 \\
\hline & & $\left(37^{\circ} \mathrm{C}\right)$ & 5.28 & 5.22 & 5.17 & 5.10 & 5.01 & 4.85 & 4.7 \\
\hline \multirow{3}{*}{3} & \multirow{3}{*}{ Brix } & $\operatorname{Room}\left(27^{\circ} \mathrm{C}\right)$ & 71 & 71 & 71 & 71 & 71 & 70 & 70 \\
\hline & & Refrigeration $\left(7^{\circ} \mathrm{C}\right)$ & 71 & 71 & 71 & 71 & 71 & 71 & 71 \\
\hline & & $\left(37^{\circ} \mathrm{C}\right)$ & 71 & 71 & 71 & 70 & 70 & 70 & 69 \\
\hline \multirow[t]{3}{*}{4} & \multirow[t]{3}{*}{ Reducing sugar } & $\operatorname{Room}\left(27^{\circ} \mathrm{C}\right)$ & 13 & 13.3 & 14.2 & 14.8 & 15.3 & 16 & 16.5 \\
\hline & & Refrigeration $\left(7^{\circ} \mathrm{C}\right)$ & 13 & 12.9 & 13.2 & 13.7 & 14.1 & 14.6 & 14.9 \\
\hline & & $\left(37^{\circ} \mathrm{C}\right)$ & 13 & 13.5 & 14.1 & 14.9 & 15.5 & 16.2 & 16.8 \\
\hline \multirow[t]{9}{*}{5} & \multirow{3}{*}{$\begin{array}{l}\mathrm{L} \\
\text { Colour a } \\
\mathrm{b}\end{array}$} & \multirow{3}{*}{$\operatorname{Room}\left(27^{\circ} \mathrm{C}\right)$} & 11.81 & 5.98 & 5.66 & 7.85 & 3.11 & 3.05 & 2.80 \\
\hline & & & -1.58 & -0.49 & -1.29 & -1.40 & -0.55 & -1.47 & -0.35 \\
\hline & & & 0.83 & -0.79 & 0.87 & 0.61 & 1.38 & 1.37 & 0.25 \\
\hline & \multirow{3}{*}{$\begin{array}{l}\text { L } \\
\text { Colour a } \\
\text { b }\end{array}$} & \multirow{3}{*}{ Refrigeration $\left(7^{\circ} \mathrm{C}\right)$} & 11.81 & 8.68 & 4.65 & 6.08 & 6.33 & 5.05 & 3.49 \\
\hline & & & -1.58 & -1.13 & -0.15 & -0.91 & -2.77 & -1.20 & -0.90 \\
\hline & & & 0.83 & 0.6 & -1 & 0.29 & 2.41 & 1.96 & 0.51 \\
\hline & \multirow{3}{*}{$\begin{array}{l}\text { L } \\
\text { Colour a } \\
\mathrm{b}\end{array}$} & \multirow{3}{*}{$\left(37^{\circ} \mathrm{C}\right)$} & 11.81 & 6.32 & 7.51 & 5.45 & 3.10 & 2.49 & 2.53 \\
\hline & & & -1.58 & -0.16 & -1.33 & -0.05 & 0.21 & -0.45 & -0.85 \\
\hline & & & 0.83 & -0.6 & 0.85 & -0.43 & 0.56 & -0.21 & 0.67 \\
\hline
\end{tabular}

\section{Colour Analysis}

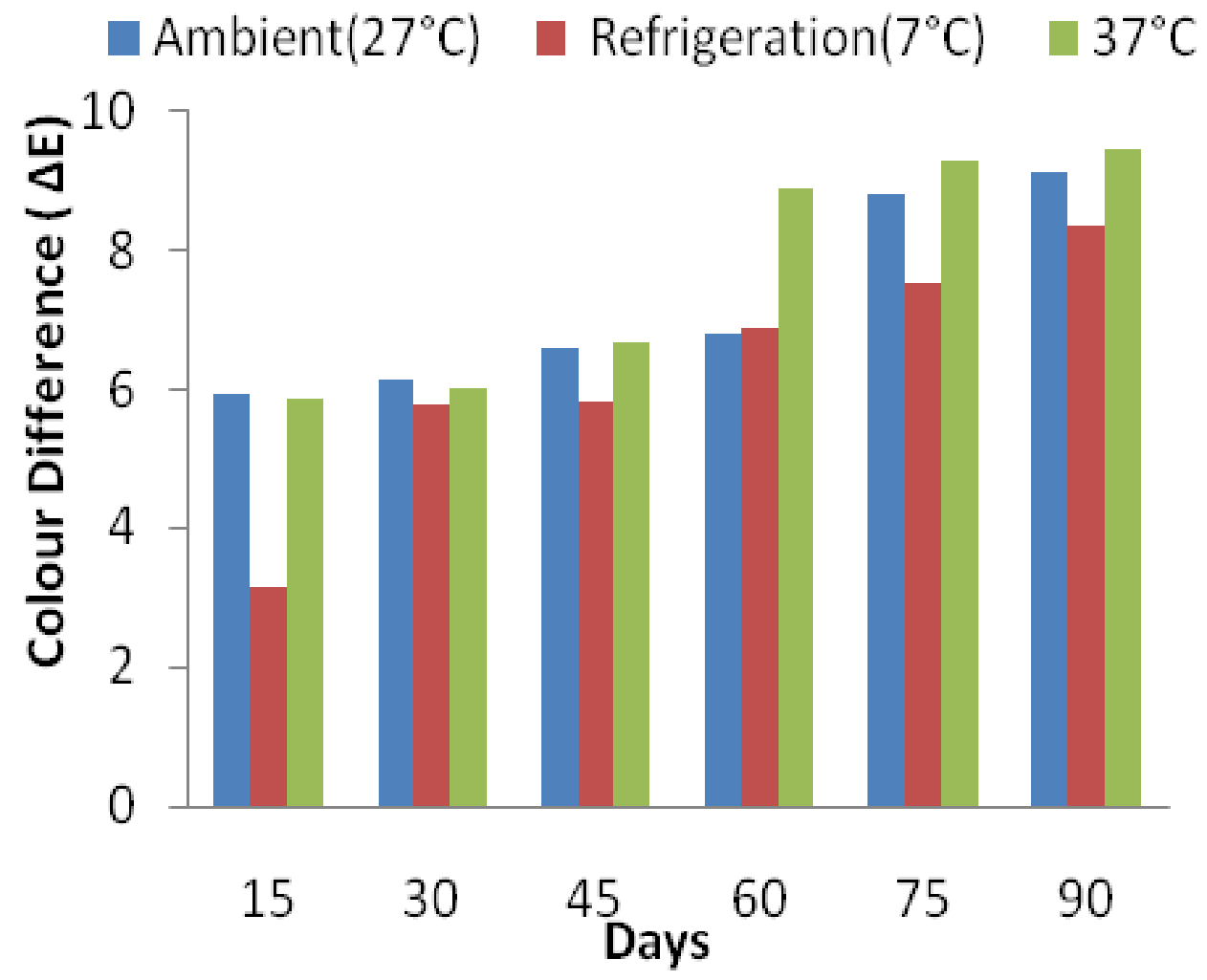

Chart-2: Colour difference of liquid jaggery during storage. 
Colour is one of the important quality factor that determines the consumer's acceptability. There was a significant effect of storage condition and period on colour of liquid jaggery (Chart 2). Samples stored at refrigeration had the lighter colour; whereas at $37^{\circ} \mathrm{C}$ was observed as darken in colour.

\section{CONCLUSION}

It can be concluded from the facts stated above that liquid jaggery without adding preservatives at refrigeration found to desirable amongst all the samples and can be stored up to 90 days without having much affect on its physico-chemical properties. We can predict that increasing reducing sugar and absorption of moisture set up favorable condition for inversion. From the results of the study, refrigeration temperature helps to extend the shelf life of liquid jaggery without adding preservatives

\section{ABBREVIATIONS AND NOMENCLATURE}

PET- Polyethylene terepthalate

DNSA-Dinitrosalicyclic acid

\section{ACKNOWLEDGEMENTS}

At this moment of accomplishment, I pay thanks to my guide, Dr.S.V Anekar, Chemical Engineering Department, Tatyasaheb Kore Institute of Engineering and Technology, Warnanagar, Kolhapur. This work would not have been possible without his valuable guidance, support and encouragement. Under his guidance I successfully overcame many difficulties and learned a lot. His energy and clear way of thinking were the driving force for me at all stages.

\section{REFERENCES}

[1] Sneh Sankhla, Anurag Chaturvedi, Aparna Kuna , M. Shreedhar, "Studies on Effect of Packaging Material and Irradiation on Storage Stability of Jaggery", volume-13(3),229-235,2011

[2] Preeti Shukla, "Effect of edible coating and packaging on microbiological characteristics of jaggery", volume-2(4),121-125, 2012.

[3] PVK Jagannadha rao, Madhusweta Das, SK Das, "Jaggery-A traditional Indian sweetener", volume 6(1), 95-102, Indian Institute of Technology, Kharagpur, 2007.

[4] Dr.Gururaj Hunsigi, Sugarcane in agriculture and Industry, Kama taka Institute of Applied Agricultural Research (KIAAR),Bagalkot.

[5] P.A Unde, P.V Adagale, Syed Imran Hashmi and Abdul Raheem, "Effect of different particle sizes of jaggery powder on storability", volume-7(2),157160, IDOSI Publications, 2011.

[6] Jaswant Singh, R.D. Singh, S.I Anwar, "Alternative sweeteners production from sugarcane in India : Lump sugar(jaggery)" volume-13(4),366-371, Society for sugar research and promotion 2011.

[7] J.K.Gehlawat, "Monograph on jaggery and Khandsari" 78-90,78-101, Indian Institute of technology, Kanpur, 1994
[8] V. K. Jagannadha Rao, Madhusweta Das , Susanta K. Das, "Effect of moisture content on glass transition and sticky point temperatures of sugarcane, palmyra-palm and date-palm jaggery, International Journal of Food Science and Technology, 2010.

[9] Amit Kumar Dwivedi, “An Empirical Study on Gur (Jaggery) Industry "Indian Institute of management" 2010

[10] O. P. Chauhan, Dheer Singh, S. M. Tyagi, and D. K. Balyan, "Studies on preservation of Sugarcane juice ", volume-5(1), 217-229, Govind Ballabh Pant University of Agriculture and Technology, 2002

[11] Technologies developed by Indian Institute of sugarcane research(IISR),Lucknow.

[12] Technologies developed by Indian Institute of sugarcane research(IISR),Lucknow. 